\title{
PUBLIC ADMINISTRATION AS AN OBJECT OF ADMINISTRATIVE AND LEGAL REGULATION
}

\section{Nenko S. S.}

\section{INTRODUCTION}

Most of the rules of administrative law regulate public relations in the field, which in the doctrine of most foreign countries are defined as "public administration".

In Ukraine, until recently, this term was not widely used; the term "public administration" was more popular, which unnecessarily narrowed the content of the concept. After all, first of all, speaking about public administration, we consciously remove from it the activities of local governments, which always perform certain functions of the state. Second, and more importantly, the term governance does not reflect the underlying nature of the category being analyzed. Public administration by its very name implies its focus on the implementation of public, that is, people's interests.

As for the competition of the words administration-management, it is necessary to put an equal sign between them, only their etymology is distinctive, and the content is the same. Given the consideration in this guide of foreign doctrine, in which the Latin root of the word administration is used in most European languages, we consider it appropriate to use only this term. Moreover, its translation into Russian and Ukrainian resulted in a onesided interpretation of the essence of the administration in the Soviet period. It is meant that in the majority of Ukrainian textbooks from administrative law only one of meanings of translation of the term administration management, management is given, instead of other service is mentioned. After all, the idea of public administration serving the interests of the people is a "red thread" in the administrative law of many countries.

What is public administration? There is no definite answer to this question. In the next section we will find out that, not only representatives of the law, but also by economists, sociologists, political scientists and other scientists study public administration. However, even among lawyers there is no common approach, although certain generalizations can be made.

Public administration is considered mainly in two aspects: structural and procedural.

According to the structural approach, public administration is defined as a set of different organizations performing public functions. These 
organizations, according to Ukrainian legal terminology, it is advisable to include executive authorities; Executive bodies of local self-government.

In the context of the structural approach, the term administration is used quite often in Ukraine. In particular, our legislation establishes the following names of organs such as State tax administration, regional state administrations, etc.

As for the procedural approach, its essence is illustrated by the definition of the well - known Polish expert in the field of administrative reform Michal Kules: "Public administration is a set of organizational actions, activities and activities that are carried out by various entities and institutions on the basis of the law and within the limits defined by law to achieve public interest. In the Ukrainian literature, the functional approach is also predominant. In particular, in the Academic course "Administrative law of Ukraine" Professor V. Averyanov defines public administration as "normmaking and administrative activity of Executive authorities for the purpose of power-organizing influence on the relevant public relations and processes in the economic, socio-cultural and administrative-political spheres, as well as internal organizational activity of the apparatus of all state bodies to ensure the proper implementation of their tasks, functions and powers" Despite the fact that this is a definition of the concept, which is only an integral part of public administration, however, the orientation of the definition seems obvious.

Both approaches have a right to life, because they consider the same category from different angles. That is, for a full understanding of the concept of "public administration" it is necessary to take into account both approaches to its understanding: structural and procedural. This position was embodied in the definition of the Russian administrativist N. Shtatinoy, which defines public administration as "the organization and activities of bodies and institutions that are devoted to political power, ensuring the implementation of the law, acting in the public interest and endowed with the prerogatives of public power" ${ }^{1}$. We believe that this definition is quite acceptable for determining the essence of public administration, especially since it reflects its main features: public administration is subject to political power (i.e., Parliament and the head of state); public administration ensures the implementation and application of laws (i.e., implements in practice the political decisions of Parliament); public administration acts (must act) in the public interest (which is appropriate to understand a reasonable combination

${ }^{1}$ Ozerska S., Polansky Y. System derzhavna service evropeiskih countries: Great Britain, Rosiyska Federation, Ukraine, Francuska Respublka. Naukovo-analtica dozen / S. Ozerska, J. Polansky. Kyiv : Staryi the UAD, 1999. P. 125-130. 
of the interests of an individual and society as a whole); public administration is vested with the prerogatives of public authority (i.e., the powers of authority that allow the public to give mandatory instructions to individuals $^{2}$ ).

Concluding a brief description of the basic concept for foreign administrative law, we note that both aspects of public administrationstructural and procedural - will be covered in more detail in parts of this guide. In particular, its second section is devoted to the characteristics of structures related to public administration, and the fourth-forms and procedures of administrative activity ${ }^{3}$.

\section{Theory of public administration and its interaction with administrative law}

A separate analysis of one, at least the most important concept for administrative law is due not only to its wide application in foreign administrative-legal doctrine and administrative legislation. A more significant reason is the significant influence of a separate science-the theory of public administration (which, again, we still call the theory of public administration on administrative law. This science, as already noted, has an interdisciplinary character and scientists from different spheres consider public administration from their own point of view.

Economists study public administration from the point of view of the ratio of the total costs of its maintenance for the society and the results that are achieved because of its activities. They try to suggest ways to increase productivity and efficiency, the social effect of administrative activities.

Sociologists consider public administration in the context of its influence on the ordering of social processes. It is the sociological concept of max Weber's "ideal" bureaucracy as a separate social position.

Political scientists study public administration as an object of influence of political power, and on the other hand can outline the forms of reverse influence of administrative structures on the bodies that form politics in the state.

Psychologists analyze public administration as a complex mechanism of psychological interaction of people. In particular, they note the significant impact of the nature of relations between public servants on the efficiency of

2 Jean Charles Adre. Review of local government in France / Jean Charles Adre; Translation of the PSP. St. Petersburg, 1994. 148 p.

${ }^{3}$ General information on the administrative law of France. Moscow: publishing house of the Embassy of France in Moscow, 1993. 316 c. 
administrative activities, justify ways of coordinating interests in conflict situations.

This list of the influence of individual Sciences on the development of the theory of public administration can be continued, but even in this volume it confirms a very broad subject of research, can be defined as the search for ways to improve the organization and activities of administrative structures. However, we, lawyers, are primarily interested in how knowledge of this interdisciplinary science affect the branch of law, which will be considered in this guide.

It can be generally argued that the theory of public administration reveals objectively existing patterns in the field of administrative activity and based on this formulates appropriate recommendations, and administrative law turns these recommendations into existing legal standards. Thus, despite the severity of the recognition of this by lawyers, administrative law performs a service function in relation to the science of public administration. The task of administrative law is to express the provisions of the science of public administration in a specific legal language in the form of legal norms. That is, we can consider the relationship of these disciplines as a matter of content and form.

One example is the use in legislation of the idea of one of the founders of the science of the administration of the American President and Professor Woodrow Wilson that the change of political leadership should not affect the activities of the permanent administrative apparatus. In Ukraine, this provision is enshrined, in particular, the norm of the article of the Law "on public service", according to which a change in the heads or composition of state bodies may not be the basis for termination of public service by a civil servant in his position on the initiative of newly appointed officials.

A number of theses of the mentioned model of "ideal bureaucracy" by max Weber today seem banal or self-evident "were also originally born in the science of public administration and only after that were fixed by legal norms. Let us name only a few of them: the hierarchy of the organization of administrative institutions; a clear assignment of competence to each institution and, accordingly, the division of competence between institutions; the appointment of civil servants on the basis of professional qualifications, education or examinations; control of employees and their subordination to the requirements of internal organizational discipline $e^{4}$.

Obviously, there is no need to prove that these ideas are embodied in the current legislation of most countries.

${ }^{4}$ Bradley A., Ewing K. Constitutional and Administrative Law. 14th Ed. Pearson Education Limited, 2007. P. 657. 
But here we turn to the opposite-the role of administrative law and its influence on public administration. Fixing in legal norms a certain order of the organization and activity of public administration, the right plays a positive role, establishing rigid frameworks of its functioning. But limitation by law is a positive to a certain limit.

As for administrative activity, its legal overregulation can lead (and leads in many cases) inflexibility of public administration in constantly changing public relations, and, as a consequence, decrease of its efficiency. To this may be added a purely formal application of legal norms by officials, resulting in suffering the interests of private persons, and, accordingly, not satisfied the public interest. To avoid this situation in recent years in foreign countries there is a reverse trend, which experts define as "slipping public administration out of the control of traditional administrative law... this does not mean that officials violate the law, but it is about finding other, more effective forms of public tasks".

This state, unfortunately, is not yet typical for Ukraine. In the national system of law, for example, administrative procedure law is still in its infancy. Administrative law as a whole, since about 1998 (when the Concept of reform of administrative law of Ukraine was developed) is in a state of permanent reform and rethinking of basic categories. A considerable achievement is the radical changes in the administrative and legal doctrine of the last time, but they should be clearly reflected in the existing legal acts and practice of administrative and legal relations.

Concluding a brief review of the relationship between the theory of public administration and administrative law, we note that under all conditions, the first of these Sciences has a significant impact on the majority of administrative and legal institutions. A significant exception is, however, the various types of external control over the public administration, but there are interdependencies 5 .

On the other hand, without administrative law, the public administration of any country simply cannot function normally. As noted by the Professor of Ukrainian origin G. Atamanchuk, "the legal aspects of management are fundamental to the practice of management, because their ignorance (or ignoring) often turns management decisions and actions into negligible" . With this thesis, we will proceed to the direct consideration of the foundations of the foreign doctrine of administrative law.

${ }^{5}$ Administrative law of foreign countries: Textbook / E. Kozyrin and M. Shmatova. Moscow; Spark, 2003. P. 288-289.

${ }^{6}$ Yankovsky N. Legal bases of functioning of municipal services in the European countries / N. Yankovsky. Vladivostok: Sphere of housing and communal services, 2007. 340 p. 


\section{Administrative law in modern legal systems}

The historical development of administrative law confirms the above positions regarding the primacy of the science of public administration, which with one name or another and the volume of research preceded the formation of the legal discipline analyzed by us. However, at a certain historical stage, it was the legal aspects of public administration that began to be recognized as essential for its normal functioning.

On the other hand, the formation of administrative law was closely related to the evolution of the state, and, in particular, the form of state government and state (political) regime. After all, it was only with the restriction of the power of monarchs and its full or partial transfer to democratically elected representatives of the people that a detailed legal regulation of the activities of not only individuals, but also the administration was recognized as necessary ${ }^{7}$.

The formation of administrative law as a set of legal norms can be divided into three stages:

The origin of administrative and legal regulation, justified by interdisciplinary science "cameralistics" (16-19 century).

The formation of a separate group of legal norms, which was called "police law" (18-early 20th century).

Transformation of police law" into "administrative law "(late $19^{\text {th }}-$ $20^{\text {th }}$ century).

As for the first stage, the science of cameralism can be safely called the forerunner of the modern science of public administration. The Latin term camera means Royal, that is, the state Treasury, and the corresponding science was intended to suggest ways to best fill this Treasury. In other words, research cameralistiv were aimed at the primary satisfaction of the interests of the state, which was associated in the period of absolutism Royal power (here it is worth remembering the famous saying of the French king Louis XIV "the state - it's me").

Cameralistics was an interdisciplinary science encompassing comprehensive knowledge of political, economic, financial, and legal issues. One of the leading Polish administrativists Y. Shrenyavski thus identifies three main areas of research cameralistiv 18-19 century: the first, under the influence of mercantilism, concentrated mainly on economic problems, the second, associated with the concept of natural law, analyzed the problems of state interventionism and protection of the interests of the rich Philistines, the third was associated with the dogmatic concept of law on the system of

${ }^{7}$ Maurer N. Allgemeines Verwaltungsrecht. Verlag C. Beck, Munchen, 2004. S. 115185. 
administrative Consequently, a certain amount of knowledge appears within the framework of cameralism, which according to today's classification can be called administrative and legal, because they concerned both the organization of public administration and the regulation of its relations with various segments of the population.

However, given the considerable and constantly growing volume, the legal aspects of Desk science at a certain stage stood out in a separate discipline called "police law". Its name comes from the Greek term police city and is literally interpreted as a set of rules that ensure public administration in cities. At first, this industry had a very broad subject of legal regulation, which covered relations in all spheres of public administration: economic and financial activities, education, health, public order. However, over time, the subject of police law began to narrow and in the 19th century with various variations provided, in particular, the following groups of public relations: the protection of the security of the state; ensuring order in public places; activities to regulate public morality ${ }^{8}$.

Police law was characterized by the priority application of prohibitions as methods of legal regulation and various forms of state coercion. In other words, the rules of this industry gave the public administration authorities broad powers over private individuals, and the latter were entrusted mainly with the duties of complying with the regulations of the administration. That is, the interests of the state were primary in the norms of police law, the interests of the person-derivatives.

The origin based on police administrative law should be attributed to the end of the 18th century or, more precisely, the period of the French revolution. It was then with the restriction of the power of absolute monarchs by popular representations that the ideas of legislative restriction of public administration developed. This process was also directly related to the adoption of the concept of the rule of law, one of the tenets of which is the observance of legal norms not only by citizens, but also by public authorities, including administrative structures.

Therefore, about the transformation of administrative law in the police can only speak when it sets in its rules, together with rights of public authorities and corresponding duties of individuals and the rights of citizens against the administration and the relevant obligations of the administration towards citizens. It is worth noting that in countries with a de facto totalitarian regime, under the name of administrative law often contained a

${ }^{8}$ Shishkin V. System of administrative jurisdiction in France. Law Of Ukraine. 1996. No. 7. P. 43-46. 
set of legal norms; in their content and orientation meet mainly the characteristics of the law of the police.

The transition to administrative law was very aptly defined by the classic of Ukrainian administrative law Professor Y. Paneyko "Administrative law is not possible in those relations in which state bodies are guided solely by the expediency and interests of the state, and are not limited to legal norms, in such relations we can only talk about administrative technology. Deserve then, as the activities of administrative bodies will be normalized by law, when there will be a smooth restriction of ad-ministration and protection of the rights of units-only then can we talk about administrative law".

The recognition of the need to establish legal limits on the activities of the public administration also raised questions about the appropriateness of various forms of control over it. In France, which is considered the birthplace of administrative law, this manifested itself in a special way. Control over the organs of public administration was entrusted not to the ordinary courts, which the new bourgeoisie distrusted because of their bias in the pre-revolutionary period, but to a special system of judicial bodies, which were authorized to hear claims of private persons against the administration. That is, administrative law is formed as a branch that ensures legal equality of citizens and public administration before the bodies of independent judicial control ${ }^{9}$.

In summary, we will try to outline the ratio of administrative and police law:

Police law regulates only part of public relations, which is provided by administrative law, that is, it can be argued that the police is under the administrative branch.

Police law is mainly aimed at protecting the interests of the state, the welfare of all, while administrative law, meanwhile, and is an effective way to protect human rights and citizens from illegal actions of administrative bodies.

Administrative law establishes a strict legal framework for the organization and activities of public administration; in police law, these aspects are not decisive.

Administrative law has developed very unevenly both in the temporal and in the territorial dimension. Significant differences have been and remain between the countries belonging to the two most common legal systems: continental (Romano-German) and Anglo-American (common law). Therefore, a more detailed consideration of administrative law will continue in accordance with this division.

${ }^{9}$ Yankovsky N. Legal bases of functioning of municipal services in the European countries / N. Yankovsky. Vladivostok: Sphere of housing and communal services, 2007. 340 p. 
The subject of administrative law in the Anglo-American legal system

The history of the development of administrative law in the AngloAmerican legal system differs significantly from the continental one. Therefore, the subject of administrative and legal regulation in the countries belonging to this system was formed with certain differences.

If we turn to the authoritative in the United States of America legal dictionary "black's law dictionary", the definition of administrative law in it is quite unusual for us: "Administrative law is a part of the law created by administrative agencies in the form of rules, instructions, regulations and decisions of these agencies" 11 . This definition, obviously, is not complete, since it does not take into account the legislative component of the administrativelegal array, but only the Bylaw, but focuses on the key concept for American administrative law "administrative Agency". It is with this concept that the formation of the analyzed industry in the United States is connected.

As you know, the American Constitution of 1787 provided for a clear division of state power into legislative (Congress), Executive (President) and judicial and a certain period of constitutional norms were observed very clearly. However, the need for economic development has led to the need for state intervention in economic processes and the feasibility of creating separate administrative bodies that would not only implement the decisions of the Congress and the President, but also independently regulate the activities of business structures. Formally, this contradicted the principle of separation of powers, because administrative bodies began to perform a legislative function, but practice has proven the effectiveness of this model. The first administrative Agency, the Interstate Commerce Commission, was created one hundred years after the Constitution was approved in 1887, and this year is considered the time of the birth of American administrative law.

Since the creation of administrative agencies did not conform to the constitutional and legal principle of separation of powers, and at one time they were even called the fourth power, which directly interferes with the rights and freedoms of citizens and corporations, the administrative law of the United States emerged as a means of protecting the rights of individuals from the new public authorities. The most important, from the point of view of American lawyers, are the procedural rules that regulate in detail the relations of administrative agencies and individuals. At the same time, administrative law regulates the forms of influence of administrative agencies on citizens and corporations, as well as feedback-the ways of influence of the latter on the decisions taken by the Agency established by the legislation. Defining the subject of us administrative law, there are three main groups of legal norms:

- the norms defining the procedure for adoption by administrative agencies of normative-legal acts( rulemaking); 
- the norms establishing the procedure for consideration by agencies of individual administrative cases (adjudication);

- the norms providing judicial review of decisions of administrative agencies (judicial review).

The listed groups of legal norms are undoubtedly administrative and procedural and are characterized by an external direction. This allowed some American authors to argue that the organization of the administrative system and the structure of individual institutions are not subject to the regulation of this industry. This position does not fully reflect the reality. As the American Professor Peter Schuck observes, the course of administrative law usually begins with a consideration of the questions: how and why administrative agencies were created; how they differ from the legislative and judicial authorities; how, in light of these differences and the lack of a constitutional definition of the legal status of agencies, can there be a reasonable delegation of legislative, judicial and Executive power to agencies; formal and informal mechanisms through which the legislative and Executive power control agencies ${ }^{10}$.

That is, despite the fact that the internal organization of the administrative agencies do not consider the impact of the object of administrative law, certain aspects of public administration cannot be excluded from the scope of regulation of administrative law, and, especially, the science of administrative law. This is confirmed, in particular, by the content of textbooks on administrative law, in which certain aspects of the organization of administrative agencies (creation and liquidation, appointment and dismissal of managers) are covered in sections on the control of the legislative and Executive authorities by administrative discretion ${ }^{11}$.

Despite the above, the prevailing administrative law of the United States is undoubtedly the administrative procedural rules that provide mechanisms for the implementation and protection of the rights of individuals in their relations with public administration. After all, administrative agencies during the 20th century received significant powers, in the implementation of which human rights are often violated. And it is Administrative law as a set of legal norms that acts as a means of limiting the abuses of the administration and protecting the rights of citizens and corporations.

In the UK, the expediency of the existence of administrative law was not recognized for the longest time-until the mid-20th century, when the number of administrative bodies began to grow steadily and, accordingly, began to appear the first comprehensive studies in this area. Taking into account the

${ }^{10}$ Administrative law of foreign countries: Textbook / E. Kozyrin and M. Shmatova. Moscow; Spark, 2003. P. 288-289.

${ }^{11}$ Melnik R. System of administrative law Nimechchini. Publci right. 2011. No. 3. P. 50. 
peculiarities of the historical development of this state, the organization of British administrative structures, their forms and the order of judicial and other types of control have significant differences. The administrative law regulating these issues only acquires signs of system.

As the modern British Professor Denis Galligan notes, administrative law, being a set of rules on the ways of exercising government power, answers such questions: what bodies and institutions form the administration and what powers they are endowed with; what is the origin (justification for the existence) of the rules that apply these bodies and institutions; to what extent these rules are implemented in daily practice; to which limits administrative-legal rules and procedures ensure fair treatment of administration to individuals ${ }^{12}$.

Considering the administrative-legal doctrine of this country, it is necessary to agree with the thesis that the British administrativists consider the main task of administrative law to maintain a balance between the need to have an effective administrative power and the protection of individuals and society as a whole from the abuse of this power. According to these legal norms, the boundaries of administrative power, its subjects and the procedures for their activities should be established ${ }^{13}$.

Summing up a brief overview of the subject of administrative law in the Anglo-American legal system, we note such features that are common to both the United States of America and the United Kingdom, and for other States that use their doctrine (primarily the British Commonwealth): the practical orientation of administrative and legal re-regulation; provision of administrative and legal norms in the vast majority of external relations between public administration and individuals; special emphasis is placed on administrative procedural norms associated with administrative law; protection of interests of citizens and corporations from abuse of power by public administration bodies and their employees is considered as the main purpose of administrative law.

The subject of administrative law in the continental legal system

Administrative law in continental Europe developed more and faster in two countries - France and Germany. Accordingly, all other States to some extent borrowed the achievements of these countries in the analyzed area. In particular, it is possible to find much in common in administrative law of Italy, Spain, Belgium with French, or Austria, Poland, Czech Republic,

${ }^{12}$ O. Mayer, Deutsches Verwaltungsrecht. - Verlag von Duncker \& Humbold. Berlin, 1924. S. 69-70.

${ }^{13}$ Maurer N. Allgemeines Verwaltungsrecht. Verlag C. Beck, Munchen, 2004. S. 115185. 
Latvia-with German. Therefore, we will focus on the experience of the two countries that have most led to the formation of modern administrative law.

Like the countries of the Anglo-American legal system, in France of the 19th century, administrative and legal regulation also focused on the procedural aspects of the relations of public administration with private individuals and, especially, the resolution of disputes between them. However, as the French economist Breban notes, in the 20th century such a methodological approach was abandoned, because conceptually it is better to first study the schematic diagram of the management mechanism, and then find out the reasons leading to failures in its work.

Professor Weil, saying that the time will come when before investigating pathology, it is necessary to thoroughly study anatomy, figuratively expressed this idea.

In other words, the issues of the system of public administration bodies, their relations with each other both vertically and horizontally, as well as the internal structure are now considered an integral part of the subject of administrative and legal regulation. In addition, unlike the countries of the Anglo-American legal system, French administrative law traditionally has a special place in the consideration of public service issues.

As already mentioned, the control of public administration in this country has been entrusted to specially create specialized courts, whose activities are also provided mainly by administrative and legal norms.

Consequently, the subject of administrative law in France includes public relations on the organization of administrative structures and their status as subjects of public law; the principles of administrative structures; the legal status of public servants; the organization and functioning of administrative courts, which consider disputes with administrative structures.

In General, administrative law as a set of existing legal norms in France is considered a very positive phenomenon for citizens and the state stabilizes public relations. Believe that it has helped to ensure a proper balance between the rights of the administrative bodies and their responsibilities; between the exclusive prerogatives of the administration and the constraints contained in the General principles of administrative law (on which we will concentrate); between the operational activities of the administration and administrative justice that watching her ${ }^{14}$.

German scholars made a particularly significant contribution to the development of administrative law. In this country, the subject of legal

14 Administrativni proceduri I administrativne sudochinstvo in Nimechchini. Zbirnik Materialiv. Nimetsky Fund of the people's legal spivrobitnitstva in Ukraine. Stephanolithion. Kiev / Bonn, 2006. P. 111-170. 
regulation of this industry is closely associated with the public administration (management). As noted by Professor Peter Lehmann, management and administrative law are in a state of mutual independence: on the one hand, according to current views, administrative law binds administrative activities, and, on the other hand, the very existence and content of administrative law depends on what place is occupied and what tasks are solved by administrative bodies according to the Constitution of the state $^{15}$.

The analyzed branch in Germany is as clearly structured as possible and consists of two parts: General and special administrative law. General administrative law contains rules that ensure the activities of all administrative bodies, regardless of the scope of competence. Special administrative law regulates certain spheres of functioning of administrative structures. In particular, administrative law in Germany includes: public service law; municipal law; police law; economic administrative law; social assistance law; construction law; environmental law; law of roads and communications; educational law, etc.

The administrative-legal doctrine of Poland concerning the internal division of administrative law is also interesting. In most Polish textbooks we find the thesis that administrative law is conditionally divided into three parts: the law of "organization" (structural and organizational), material law and procedural law. Such a division should answer the questions: who does, what does, how does.

The structural and organizational part includes the norms regulating intra-organizational relations in public administration: it defines the system of bodies, the internal structure of individual bodies, tasks, forms and methods of activity.

The substantive administrative law includes the norms establishing mutual rights and obligations of public administration bodies with private persons (both legal and physical).

Procedural (procedural) administrative law in Poland can be divided into two groups of rules: General (procedures for the functioning of all public administration bodies, as well as the process of judicial control over their activities) and special (features of the implementation of administrative procedures in individual bodies, for example, tax).

As already noted, this division is conditional, but it forms a holistic picture of administrative and legal regulation.

${ }^{15}$ Garner D. Great Britain: Central and local government: TRANS. / D. garner; ed., ed. Preface. G. Barabashev, N. Shulzhenko, V. Entin. Moscow: Progress, 1984. P. 23. 
Summarizing this review, we note that the administrative law of the States of the continental (or Romano-German) legal system is a set of rules that regulate two groups of public relations: internal (the system of public administration bodies, their relations, internal structure and legal status) and external (legal relations between administrative bodies on the one hand and citizens and legal entities on the other). Although, according to many leading scientists, internal-organizational relations still play a supporting role in relation to external.

Correlation of administrative law with other branches of law

Administrative law is a classical branch of public law. However, the rules of this branch are closely related to other branches of public law, as well as to private law.

Already quoted French Professor Breban noted that administrative law regulates the organization and functioning of the state administration apparatus, its relationship with individual citizens, but does not regulate:

- part of the activities of administrative structures, which is provided by the norms of civil law (for example, the conclusion of a contract with a private firm for the repair of the administration building);

- policy-making is considered the prerogative of Parliament, government or head of state and falls under the regime of constitutional law. On the other hand, it is often very difficult to distinguish between political decisions directed to public administration bodies and the actual administrative activities by which these decisions are implemented;

- judicial activity to resolve disputes between citizens (civil procedural law) and to bring to justice persons who have committed crimes or misdemeanors (criminal procedural law). However, there are two very important exceptions where regulation is carried out by administrative law: the administration of justice and administrative justice.

Let's try to analyze the correlation of administrative law with the branches that are considered basic in any legal system.

- Constitutional and administrative law.

The Constitution of each country is the main normative source of the structure and activities of the administration, as well as the legal basis for a non-stop process of weighing the General and individual interests, which is the legal content of the implementation of the administration of the duties entrusted to it.23 Consequently, constitutional law establishes the basic principles of the organization of public administration, the place of its subjects in the state mechanism, the legal basis for their creation and relations with the subjects of other branches of government, as well as determines the rights and freedoms of citizens, which are implemented in this area. 
Administrative law details and concretizes the norms of constitutional law, while defining the competence of various parts of the system of public administration, forms and procedures of its activities, legal mechanisms for the implementation and protection of the rights and freedoms of citizens and legal entities in administrative relations. According to the above-mentioned division of administrative law array into three conditional parts, video gothicist constitutional and administrative law there is only a relatively structurally-or-hansating law, procedural and substantive law - is the exclusive area we analyze is the industry ${ }^{16}$.

- Civil and administrative law.

Civil law regulates mainly property relations, administrative law can regulate them, but with the participation of a mandatory subject-a public administration body (or another authorized subject) or between such subjects. The difference lies in the fact based on what forms of law relations are settled: 'a civil contract with its dispositivity or an administrative act (imperative) or an administrative contract.

In addition, the rules of administrative law actually limit the action of civil law. For example, the government or a state Agency establishes a methodology for calculating the rent for state property, and thus the parties to the contract (a private person and a state-authorized body) cannot set the price in the lease of state property arbitrarily, as is the case in civil law.

- Labor and administrative law.

Labor law, together with administrative law, regulates public service relations. It is considered that the legal regulation of labor in public administration bodies and other employees (for example, drivers or other technical workers) is the exclusive prerogative of labor law. However, in relation to persons who are called public servants, we observe a complex impact of the norms of both industries.

Administrative law establishes a special legal status for public servants, which provides for the following features: recruitment; career; rights and obligations of employees; responsibility of employees; termination of service.

At the same time, public servants are subject to labor law norms common to all employees, for example, which set the time of work and rest.

${ }^{16}$ Bogdanovskaya I. Sources of law at the present stage of development of "Common law": abstract of the thesis for the degree of doctor of law. Specialty 12.00 .01 - Theory and history of law and state; History of legal doctrines. Institute of state and law of the Russian Academy of Sciences. Moscow, 2007. P. 40. 
It is worth noting that this section applies mainly to the countries of the continental legal system, but in the Anglo-American law of public service as a separate institution of administrative law is not allocated.

- Financial and administrative law.

Financial law in many countries is considered a special part of administrative law, but given the wide scope of regulation it is almost universally singled out separately. The efficiency of both industries is manifested in the joint regulation of the functioning of the financial authorities of the state (state banks, the Ministry of Finance or the tax service). However, if financial law regulates the financial relations on mobilization, distribution and use of state funds, then administrative law regulates the procedure of formation of financial bodies, organization of their work, registration and licensing of commercial banks.

- Criminal and administrative law.

In Ukraine and other CIS countries, administrative law is very close to criminal law due to the existence of a separate institution of administrative responsibility. In most countries of both the continental and Anglo-American legal systems, the rules establishing liability for minor offenses are referred either to a separate branch (the law of law) or to criminal law. After all, this type of legal liability for minor offenses is directed mainly against private individuals, which contradicts the basic idea of administrative and legal regulation on the legal status of public administration.

- Sources of administrative law.

Theorists understand the source of law as a form of external expression of legal norms. In other words, considering the sources, we make an overview of the" location" of the right.

The source base of administrative law is rather specific, and in this context, it is possible to designate such its characteristics:

Variety and large volume of sources of administrative law. They can be acts of all branches of government: legislative (Constitution and ordinary laws), Executive (government, ministries, and local administrations) and judicial (decision of General or administrative courts). In one country, the number of administrative and legal sources cannot be accurately accounted for, but it can be argued that we are talking about at least tens of thousands of documents. The lack of a General codification of acts. Unlike criminal or civil law, where the basic legal norms are summarized in General codified acts, administrative law is not subject to such codification. This is primarily due to the very broad subject of legal regulation and its diversity. However, the codification of certain administrative and legal institutions, such as administrative procedures, is possible and exists in many foreign countries. 
The special place of subordinate legal acts issued by public administration bodies in the system of sources of administrative law. Despite the General recognition of the need and priority of regulating public administration by laws, the role of de facto by-laws is very large.

The hierarchy of sources of administrative law is a matter of Convention, and above all it concerns the countries of the Anglo-American legal system, where judicial precedents are essential. However, even in this case, it is necessary to make a generalization of sources, in which each subsequent level is not necessarily lower than the previous ones. So, the sources of administrative law include:

1) Constitutions and constitutional acts ${ }^{17}$.

As noted by German scientist X. Penchenier, the Constitution does not contain rules of administrative law in the narrow sense of the word, but forms the basis of activity of administrative bodies defines the important principles which administrative authorities are obliged to follow.

Thus, the ideas laid down in the constitutions of foreign countries become the basis for further administrative and legal regulation. This can be illustrated by the example of the Constitution of the Italian Republic of 1947, a number of provisions which directly affected this branch, establishing in particular: the principle of decentralization of the public administration (article 5); legal liability of the state and its servants for acts the Commission of which violates the rights of others (article 28); the ability to delegate legislative functions of the government: for a limited time and against a specific range of issues (article 76); legislative regulation of education and activity of state institutions (article 97); replacement of positions in public administration according to competition, except for the cases established by the law (article 97); existence of the State Council and other bodies of administrative justice exercising jurisdiction on protection of legal interests concerning actions of state bodies (article SW).

In the United States Constitution of 1787, the rules that can be considered sources of administrative law are much smaller, but they are also the basis for administrative law doctrine, legislation, and enforcement. Given the protective nature of administrative law in this country, let us first recall the provisions of section 2 of article 3 of the American Constitution, which States, "the judicial power shall extend to disputes to which the United States is a party". 26 This rule is a prerequisite for judicial control of the activities of the public administration.

${ }^{17}$ Hilgendorf, Eric: dtv-Atlas Recht / Eric Hilgendorf. - Munchen: Dt. ludschen-buchVerl. 2. Verwaltungsrecht, Zivilrecht, 2008. S. 265. 
As you know, in the UK, there is no written Constitution in the form of a single document, and a number of historical documents that can be conditionally called constitutional acts plays its role. In the context of administrative law, it is appropriate to highlight the bill of rights of 1689, which obliges the authorities to respect and observe the rights of citizens, that is, delineate the boundaries of public administration.

2) Laws and other legislative acts.

The next step on the constitutions - laws. Administrative structures cannot act as they please, but only within the limits defined by law. The legislator makes the most important decisions concerning the state and each individual citizen applying the law.

For example, in the UK, the most important sources of administrative law include: the acts of delegated legislation Act 1946, which established the procedure for the adoption and publication of administrative regulations issued by the authority of the Parliament; the tribunals and investigations Act 1958, regulating the organization and activities of the British administrative justice-administrative tribunals and Ministerial investigations (inspections); The crown claims act 1947, which summed up the practice of the courts in cases of liability of the administration for damage caused by its services ${ }^{18}$.

In continental Europe, codes occupy a special place among legislative acts. In particular, here it is possible to name the Code on administrative justice of the French Republic; the Code of administrative proceedings of 1960 of the Polish Republic.

These and other codified acts will be analyzed in more detail in the following sections.

3) Acts of public administration, equivalent to laws.

Given the inability of modern parliaments to fully meet the needs of society in the legislative regulation, in some countries practiced equating acts of public administration (especially governments) laws. For example, in the Italian Republic, it is possible to adopt two types of acts that are equivalent to laws: legislative decrees and decree-laws.

Legislative decrees are issued by the Council of Ministers (the government of Italy) based on a special act on the delegation of relevant powers adopted by Parliament. At the same time, the government may adopt legislative decrees only for a limited time, on specific issues and taking into account the criteria established by law.

${ }^{18}$ Bradley A., Ewing K. Constitutional and Administrative Law. 14th Ed. Pearson Education Limited, 2007. P. 657. 
Decrees-laws, unlike legislative decrees, the government adopts on its own initiative, but only in necessary and urgent cases. However, these acts are subject to mandatory subsequent approval by Parliament within two months, if this is not done, the decrees-laws lose their force from the moment of adoption.

These acts, which are equated with laws, often refer to reforms in public administration, thus acting as sources of administrative law.

Interestingly, the borrowing of this institution by other countries has not always stood the test of time. For example, in 1992-1997, such a possibility of adopting acts that are equivalent to laws existed in the Polish Republic, but has never been applied in practice. According to the current Constitution of Poland of 1997, the President on the proposal of the Council of Ministers can issue orders with the force of law only in the case of martial law, if the Sejm (Parliament) cannot hold a meeting.

- International treaty.

This type of source of law is also equated with laws and is considered part of national legislation and in many cases can even be found in the hierarchy of sources a step higher. For example, according to article 55 of the Constitution of the French Republic of 1958, international treaties or agreements duly approved or ratified shall, from the moment of their publication, have a force exceeding that of domestic laws, subject to the application of such Treaty or agreement by the other party. Similarly, article 25 of the Basic Law of the Federal Republic of Germany establishes that the rules of international law are an integral part of the law of the Federation, have precedence over the laws and directly give rise to rights and obligations for the inhabitants of the Federal territory.

- Decision of the constitutional court bodies.

Constitutional courts in countries where they are established and functioning may terminate acts of parliaments, heads of state and government contrary to the provisions of the Constitution. Consequently, the decisions of these courts affect the operation of administrative law and can be considered as sources of administrative law.

- Regulations of governments and Central public administration bodies.

This group is the largest among our list of sources. At the same time, each country has its own peculiarities regarding the form and content of these acts. For example, the President of the United States of America issues Executive orders; Federal departments and agencies issue orders, instructions, rules of procedure; other administrative agencies issue policies, standards, and the like. 
- Normative acts of local public administration bodies ${ }^{19}$.

This group of sources of administrative law should include normative acts of public administration in the regions and in the field; normative acts of local self-government (for example, statutes of territorial communities). Decisions of the General and administrative courts.

\section{CONCLUSIONS}

The article deals with the theory of public administration and its interaction with administrative law, administrative law in modern legal systems: the history of the formation of administrative law in foreign countries, the subject of administrative law in the Anglo-American legal system, the subject of administrative law in the continental legal system, the ratio of administrative law with other branches of law, sources of administrative law.

\section{SUMMARY}

As you know, in the countries of the Anglo-American legal system, the decisions of the courts in individual cases can acquire a binding character for subsequent decisions on such issues. Such decisions - judicial precedents are an important source of law, including administrative.

In countries of the continental legal system, judicial precedents are usually not listed among the sources of law. However, in fact, the decisions of administrative courts in continental Europe have a significant impact not only on the practice of resolving the following public law disputes, but also on the legislation and decisions of public administration bodies. Therefore, decisions of administrative (or general) courts are ranked in the following group with the name: Informal sources of administrative law.

Here, in addition to court decisions, include: customs (for example, regarding the right of courts to finally decide all controversial issues of law, traditional for the countries of the Anglo-American legal system); individual decisions of public administration (resonant administrative acts can also have an impact on law enforcement); administrative and legal doctrine (in particular, if the expertise of representatives of the science of administrative law rely on the basis of judicial decisions); posayuridichni norms (social, moral, technical).

${ }^{19}$ Bradley A., Ewing K. Constitutional and Administrative Law. 14th Ed. Pearson Education Limited, 2007. P. 657 
The informality of these sources of law means that despite their real impact on the creation and application of administrative law, they cannot be a formal legal basis for the adoption of a specific administrative decision.

\section{REFERENCES}

1. Constitution of the French Republic http://zakoni.ucoz.ru/ news/konstitucija_francii/2012-03-26-94

2. General information on the administrative law of France. Moscow: publishing house of the Embassy of France in Moscow, 1993. 316 c.

3. Vedel J. Administrative law of France. Moscow: Progress, 1973. $512 \mathrm{p}$.

4. Ozerska S., Polansky Y. System derzhavna service evropeiskih countries: Great Britain, Rosiyska Federation, Ukraine, Francuska Respublka. Naukovo-analtica dozen / Ozerska S., J. Polansky. Kyiv: Staryi the UAD, 1999. P. 125-130.

5. Jean Charles Adre. Review of local government in France / Jean Charles Adre; Translation of the PSP. St. Petersburg, 1994. 148 p.

6. Code administratif: National government publication: French : 21e. Paris: Dalloz, 1990. 1564 p.

7. Giants N. French experience of housing and communal services. UTILITIES SECTOR. 2008. No. 5. P. 14-18.

8. Yankovsky N. Legal bases of functioning of municipal services in the European countries / N. Yankovsky. Vladivostok: Sphere of housing and communal services, 2007. $340 \mathrm{p}$.

9. Shishkin V. System of administrative jurisdiction in France. Law Of Ukraine. 1996. No. 7. P. 43-46.

10. Ardan F. France: the state system / L.M. Entin (Rel.ed.), L.S. Filippova (TRANS.). Moscow: Yuridicheskaya Literatura, 1994. 176 p.

11. Control over the activities of the public administration in France. Moscow: Embassy of France in Moscow, MFA, 1994. 106 p. (RussianFrench series of educational and information materials).

12. Legal and material means of administrative activity in France / Bieyi Z. - Verpo M., Lashom Z.-F. Moscow: Ed. FR. Org. Tech. Cooperation, $1994.150 \mathrm{c}$.

13. Administrative law of foreign countries: Textbook / E. Kozyrin and M. Shmatova. Moscow; Spark, 2003. P. 288-289.

14. Melnik R. System of administrative law Nimechchini. Publci right. 2011. No. 3. P. 50.

15. Mayer O., Deutsches Verwaltungsrecht. - Verlag von Duncker \& Humbold. Berlin, 1924. S. 69-70. 
16. Maurer N. Allgemeines Verwaltungsrecht. Verlag C. Beck, Munchen, 2004. S. 115-185.

17. Hilgendorf, Eric: dtv-Atlas Recht / Eric Hilgendorf. - Munchen : Dt. ludschen-buch-Verl. 2. Verwaltungsrecht, Zivilrecht, 2008. S. 265.

18. Administrativni proceduri I administrativne sudochinstvo in Nimechchini. Zbirnik Materialiv. Nimetsky Fund of the people's legal spivrobitnitstva in Ukraine. Stephanolithion. Kiev / Bonn, 2006. P. 111-170.

19. Garner D. Great Britain: Central and local government: TRANS. I D. garner; ed., ed. Preface. G. Barabashev, N. Shulzhenko, V. Entin. Moscow: Progress, 1984. P. 23.

20. Bradley A., Ewing K. Constitutional and Administrative Law. $14^{\text {th }}$ Ed. Pearson Education Limited, 2007. P. 657.

21. Bogdanovskaya I. Sources of law at the present stage of development of "Common law": abstract of the thesis for the degree of doctor of law. Specialty 12.00.01 - Theory and history of law and state; History of legal doctrines. Institute of state and law of the Russian Academy of Sciences. Moscow, 2007. P. 40.

\section{Information about the author:} Nenko S. S.,

Candidate of Law, Associate Professor, Professor at the Department of Administrative,

Criminal Law and Procedure, International University of Business and Law 37-A, 49 HGD str., Kherson, 73040, Ukraine 